\title{
Expression of major histocompatibility class II antigens by Langerhans' cells in cervical intraepithelial neoplasia
}

\author{
R G HUGHES, M NORVAL, S E M HOWIE \\ From the Department of Bacteriology, University of Edinburgh Medical School, Teviot Place, Edinburgh, \\ Scotland
}

SUMMARY Cervical biopsy samples from 67 patients who had various grades of cervical intraepithelial neoplasia (CIN) or who showed evidence, in the form of koilocytosis, of human papillomavirus (HPV) infection of the uterine cervix, and from 10 women with normal cervices were examined. Cryostat sections from the biopsy samples were stained using monoclonal antibodies to T6, a Langerhans' cell marker, and to major histocompatibility complex (MHC) class II antigens (HLADP, DQ, and DR). Epithelial Langerhans' cells were reduced in number and showed changed morphology and distribution in koilocytic lesions and in all grades of CIN ( $p<0.01)$ except CIN I. HLA-DR expression by Langerhans' cells was significantly increased in koilocytic lesions and in CIN grades I and II ( $\mathrm{p}<0.05$ ); HLA-DQ expression was significantly increased in all grades of CIN $(\mathrm{p}<0.05)$ with the increase being most pronounced in CIN I $(p<0.01)$. Columnar epithelium expressed MHC class II antigens in all samples tested and squamous epithelium in four of 29 cases of CIN III.

These findings support the view that there is a localised disturbance of immune function in both neoplastic cervical epithelium and that infected with papillomavirus.

The association between human papillomavirus (HPV) infection and cervical intraepithelial neoplasia (CIN) has been well documented, and an increasing body of evidence suggests that this association is causal rather than casual. ${ }^{\prime}$ Other factors probably also have a role, and recent reports of HPV DNA isolation from apparently normal cervical epithelium ${ }^{23}$ would support the hypothesis that the disease develops by a multistep process.

The nature of an effective immune response to papillomavirus infections is not well understood, although cell-mediated immunity is thought to be more important than humoral immunity. ${ }^{4} \mathrm{~A}$ deficient immune response to HPV may permit the development of intraepithelial neoplasia, and a reduction in the number of antigen presenting cells has been shown in both papillomavirus infected ${ }^{5-8}$ and neoplastic cervical epithelium. ${ }^{8}$

The predominant antigen presenting cell in squamous cervical epithelium is the Langerhans' cell, a dendritic cell which may be identified by the use of

Accepted for publication 3 September 1987 monoclonal antibodies to the common thymocyte antigen T6, ${ }^{9}$ or to major histocompatibility complex (MHC) class II antigens. ${ }^{10}$ The ability of the Langerhans' cell to present foreign antigen to $T$ lymphocytes depends on the expression of surface MHC class II antigens." The level of MHC class II antigen expression by Langerhans' cells is known to vary ${ }^{12}$ and may reflect the state of "activation" of the cell. The recent widespread availability of monoclonal antibodies now facilitates study not only of the framework determinants common to all MHC class II antigens, but also the non-polymorphic products of the individual known class II loci HLA-DP, DQ, and DR. ${ }^{13-15}$

In this study we attempt to relate the number, distribution, and morphology of Langerhans' cells and their expression of MHC class II antigens (including the products of HLA-DP, DQ, and DR) to the presence of HPV infection, in the form of koilocytosis, and of CIN grades I-III.

\section{Patients and methods}

Sixty seven patients (age range 19-45 years) referred to the Lothian Area colposcopy clinic with a history of 
abnormal cervical cytology were studied. Seven women (aged 20-38) who had been referred to the colposcopy clinic for other reasons (four women on account of clinical concern about the appearance of the cervix and three women because of post-coital bleeding) and who had no cytological, colposcopic, or histological evidence of CIN were included as controls. Three women (aged 33-41) undergoing total abdominal hysterectomy for benign conditions, with a history of normal cervical cytology, were included as further controls.

A cervical biopsy sample was taken from the transformation zone of each patient and control. All the samples from the patients came from an area of colposcopic abnormality while those from the seven colposcopy clinic controls came from an area of suspected colposcopic abnormality within which no histological evidence of CIN or HPV infection was subsequently found. Those from control patients undergoing hysterectomy were taken within 15 minutes of the uterus being removed from the patient. The specimens were snap frozen on dry ice and stored at $-80^{\circ} \mathrm{C}$ until processed further. An $8 \mu \mathrm{m}$ cryostat section was cut from the centre of each and prepared for routine histopathological examination with a conventional haematoxylin and eosin stain. CIN was classified according to recognised criteria. ${ }^{16}$ Koilocytes (balloon shaped cells with a perinuclear halo) were considered to be diagnostic of HPV infection. ${ }^{17}$

Serial cryostat sections ( $8 \mu \mathrm{m}$ in thickness) were prepared, mounted on poly L-lysine coated slides, fixed in acetone at $4^{\circ} \mathrm{C}$ for 10 minutes, and air dried. Sections were then stained using an indirect immunoperoxidase technique adapted from the method of Carr et al..$^{18}$ Briefly, sections were incubated in $20 \%$ normal rabbit serum in $0.001 \mathrm{M}$ Tris-buffered saline (TBS), pH 7.6, for 20 minutes. Excess serum was shaken off and sections then incubated for 45 minutes with monoclonal antibody (table 1) at room temperature. DAKO T6 is ascitic fluid, ${ }^{19}$ and all other monoclonal antibodies are culture supernatants. ${ }^{13-1520}$ The optimal dilution of antibody made in $2 \%$ normal rabbit serum was determined by titration. Negative

Table 1 Origin and specificity of monoclonal antibodies

\begin{tabular}{|c|c|c|c|}
\hline $\begin{array}{l}\text { Monoclonal } \\
\text { antibody }\end{array}$ & $\begin{array}{l}\text { Working } \\
\text { dilution }\end{array}$ & Origin & Specificity \\
\hline DAKO-T6 & $1 / 20$ & Dakopatts ${ }^{19}$ & \multirow{3}{*}{$\begin{array}{l}\text { Langerhans' cells, } \\
\text { common thymocytes } \\
\text { HLA-DP, HLA-DQ, } \\
\text { HLA-DR } \\
\text { HLA-DP } \\
\text { HLA-DQ } \\
\text { HLA-DR }\end{array}$} \\
\hline DA6.231 & $1 / 10$ & K Guy ${ }^{20}$ & \\
\hline $\begin{array}{l}\text { B7/21 } \\
\text { TU222 } \\
\text { L243 }\end{array}$ & $\begin{array}{l}\text { Neat } \\
\text { Neat } \\
1 / 20\end{array}$ & $\begin{array}{l}\text { I Trowbridge }{ }^{13} \\
\text { A Ziegler'14 } \\
\text { American Type } \\
\text { Culture Collections }^{15}\end{array}$ & \\
\hline
\end{tabular}

controls were prepared by substituting $2 \%$ normal 0 rabbit serum for monoclonal antibody. Sections were $\overrightarrow{\mathrm{\sigma}}$ then washed in $2 \%$ normal rabbit serum and incubated with a rabbit antiserum to mouse immuno- $\overrightarrow{\vec{N}}$ globulins conjugated with horseradish peroxidase $\overrightarrow{0}$ (Dakopatts) for 15 minutes. The enzyme reaction was $\frac{c}{0}$ developed using diaminobenzidine (Sigma, Poole, Dorset). Sections were counterstained with Mayer's $\vec{\varnothing}$ haemalum, washed in tap water, and mounted in DPX after dehydration.

QUANTIFICATION OF LANGERHANS' CELLS Stained sections were photographed and the surface $\vec{\omega}$ area of squamous epithelium calculated using tracing paper. Cells possessing at least two dendrites attached to a cell body and staining positively with DAKO T6 were classified as Langerhans' cells and counts iv expressed per $\mathrm{mm}^{2}$ of epithelium, as this has been $\mathcal{\omega}$ found to be the most reliable method of enumerating $\mathrm{O}$ Langerhans' cells. $^{21}$

The significance of the difference between each group and the control group was calculated using the Mann-Whitney $U$ test.

\section{Results}

DISTRIBUTION AND NUMBERS OF LANGERHANS' CELLS

In specimens taken from normal cervical transformation zones Langerhans' cells were found predominantly in the lower half of the epithelium (fig 1). The slender dendritic processes stained strongly with DAKO T6 and appeared to link adjacent Langerhans' cells. No significant differences in Langerhans' cell morphology, distribution, number, or MHC class II expression were seen if biopsy samples from the two groups of normal controls were compared. In specimens taken from areas of CIN (fig 2) Langerhans' cells were distributed throughout the entire thickness of the epithelium and their dendrites were much shorter and less numerous. Table 2 shows that T6 positive Langerhans' cells were significantly reduced in number $(\mathrm{p}<0.01)$ in all abnormal groups except CIN I.

EXPRESSION OF MHC CLASS II ANTIGENS BY LANGERHANS' CELLS

When the monoclonal antibody DA6.231 was used the number of positively staining dendritic cells closely paralleled the number of T6 positive cells, although it can be seen from tables 2 and 3 that T6 positive dendritic cells always exceeded DA6.231 positive dendritic cells in number. Some Langerhans' cells were therefore not expressing class II antigens, or were expressing these antigens at undetectable levels. In each specimen there were some DA6.231 positive, T6 


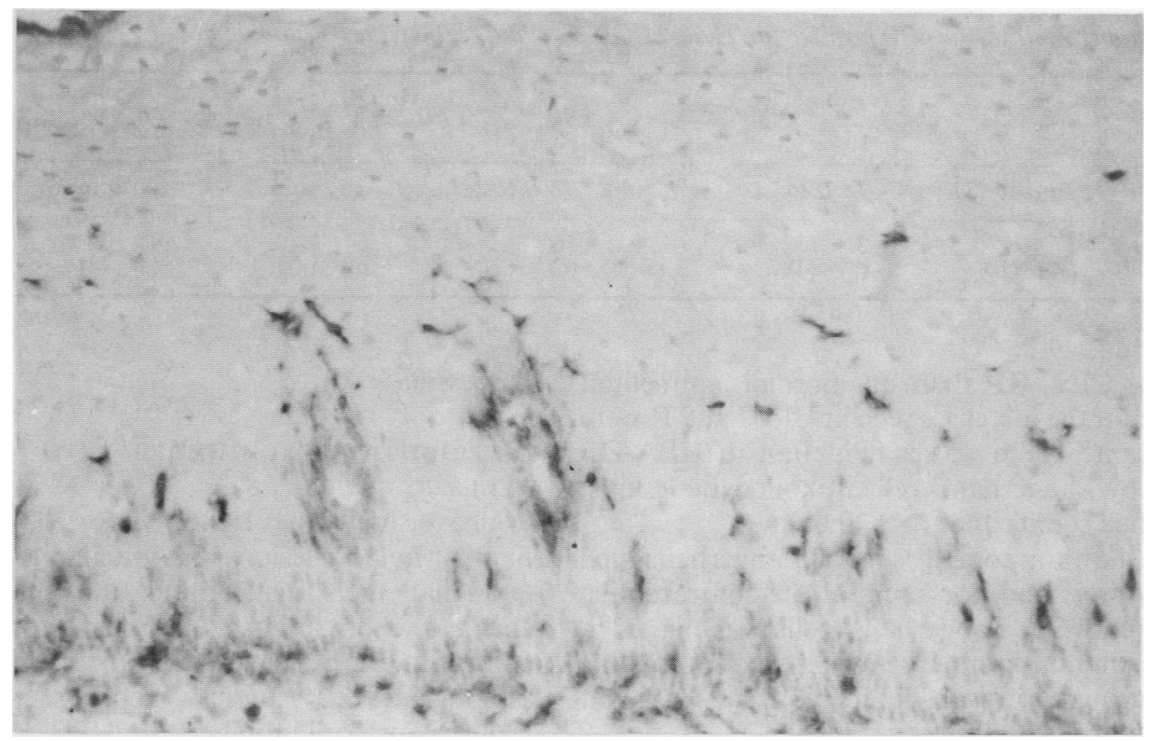

Fig 1 DAKO-T6 staining of normal cervical transformation zone showing dendritic Langerhans' cells in lower half of epithelium.

negative, non-dendritic cells, and these were assumed to be activated $\mathrm{T}$ lymphocytes. This was confirmed in some cases (results not shown) by the use of monoclonal antibodies to $\mathrm{T}$ cell markers.

Table 3 shows the pattern of expression of HLADP, HLA-DQ, and HLA-DR by Langerhans' cells. A significantly higher percentage of Langerhans' cells in koilocytic lesions and in CIN grades I and II expressed
HLA-DR when a comparison was made with HLADR expression by Langerhans' cells in normal cervical epithelium $(p<0.05)$. No increase in HLA-DQ expression by Langerhans' cells was seen in koilocytic lesions, but significantly more Langerhans' cells were HLA-DQ positive in all grades of CIN than in normal epithelium (CIN I $p<0.01$; CIN II and III $p<0.05$ ). Significantly more Langerhans' cells were HLA-DP

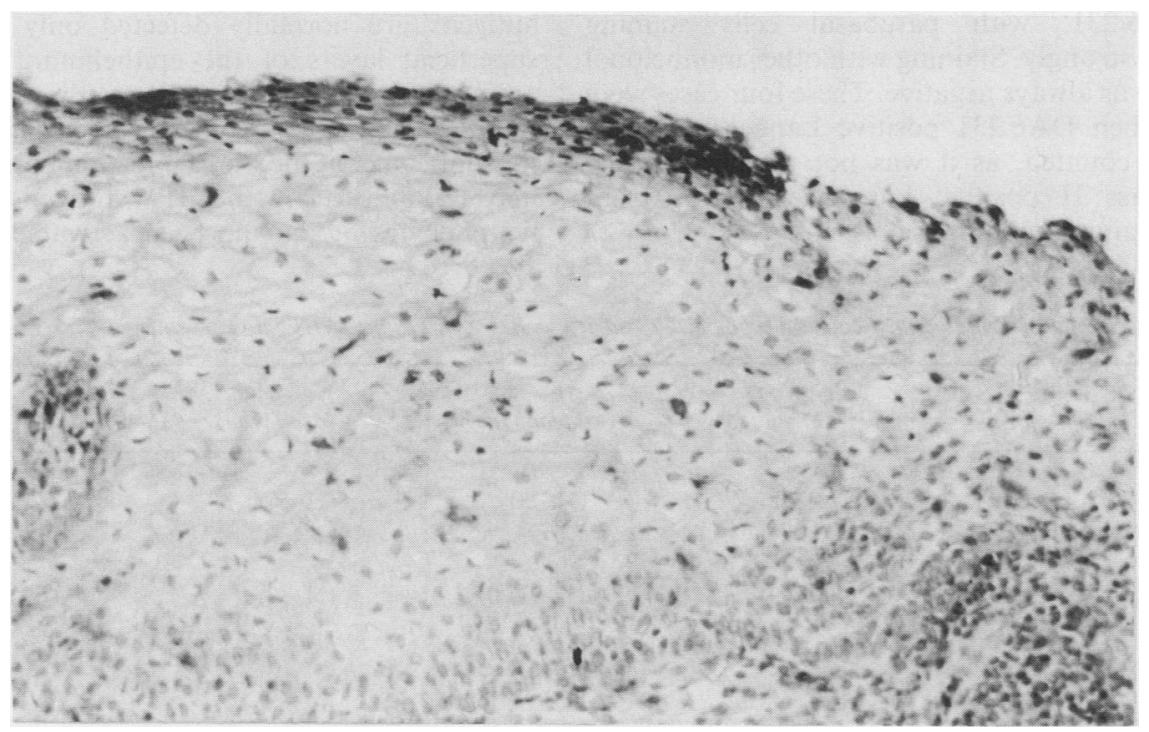

Fig 2 DAKO-T6 staining of sample of CIN I, showing Langerhans' cells throughout epithelial thickness. 
Table 2 Number of dendritic cells positive for T6 and DA6.231/ $\mathrm{mm}^{2}$ sectional area epithelium

\begin{tabular}{|c|c|c|c|c|c|}
\hline $\begin{array}{l}\text { No of } \\
\text { cells/mm }\end{array}$ & $\begin{array}{l}\text { Normal } \\
(n=9)\end{array}$ & $\begin{array}{l}\text { Koilocytosis only } \\
(n=6)\end{array}$ & $\begin{array}{l}C I N I \\
(n=21)\end{array}$ & $\begin{array}{l}C I N I I \\
(n=10)\end{array}$ & $\begin{array}{l}C I N I I I \\
(n=19)\end{array}$ \\
\hline & T6 DA6.231 & T6 DA6.231 & T6 DA6.23I & T6 DA6.231 & T6 DA6.231 \\
\hline $\begin{array}{l}\text { Mean } \\
\text { (SEM) }\end{array}$ & $\begin{array}{ll}57 & 55 \\
(12) & (10)\end{array}$ & $\begin{array}{ll}21 & 15 \\
(5) & (4)\end{array}$ & $\begin{array}{ll}36 & 35 \\
(6) & (6)\end{array}$ & $\begin{array}{ll}24 & 22 \\
(6) & (8)\end{array}$ & $\begin{array}{ll}11 & 7 \\
(3) & (4)\end{array}$ \\
\hline
\end{tabular}

positive in CIN III than in normal epithelium $(\mathrm{p}<0.01)$ but the increases seen in CIN I and II were not significant. There was a reduction in HLA-DP expression by Langerhans' cells in koilocytic lesions, which reached significance $(p<0.05)$.

Table 4 shows a comparison of Langerhans' cell numbers in users and non-users of the contraceptive pill. The number of Langerhans' cells was higher in users than in non-users in normal and in all the abnormal groups, but the difference was significant only in CIN I ( $p<0.05)$.

In three of 10 specimens from normal transformation zones and 16 of 67 specimens from abnormal transformation zones a portion of columnar epithelium was included in the sections. In all 19 cases this epithelium stained positively with DA6.231 (fig 3) but not with the other monoclonal antibodies.

Normal squamous epithelium from the transformation zone and specimens of squamous epithelium from areas of koilocytosis only, and of CIN I and II, were consistently negative with all monoclonal antibodies used. In four of 29 specimens of CIN III, positive staining of squamous epithelium was seen using DA6.231, with parabasal cells staining particularly strongly. Staining with other monoclonal antibodies was always negative. These four cases were excluded when DA6.231 positive Langerhans' cells were being counted, as it was not possible to distinguish class II positive Langerhans' cells from positively staining squamous epithelium.

\section{Discussion}

\section{DISTRIBUTION AND NUMBERS OF LANGERHANS CELLS}

We have shown that Langerhans' cells are reduced in number in HPV lesions and in CIN grades II and III, and that their distribution and morphology are changed within abnormal cervical epithelium. This is consistent with a recent report from Tay et al, ${ }^{8}$ although earlier studies ${ }^{57}$ reported a decrease in Langerhans' cell numbers in HPV lesions and an increase in numbers in CIN. It has been postulated that the papillomavirus exerts a direct cytotoxic effect on Langerhans' cells, ${ }^{5}$ and the loss of dendrites observed may be a reflection of this. Work is in progress using a technique to label Langerhans' cells and papillomaviral antigen simultaneously to investigate this. Interestingly, there was abnormal distribution of Langerhans' cells throughout dysplastic epithelium and there may be an association between this and the pattern of HPV infection of squamous epithelium. HPV DNA can be detected by in situ hybridisation in the parabasal layers but viral antigens are normally detected only in the more superficial layers of the epithelium. ${ }^{22}$ Perhaps the antigen positive cells attract Langerhans' cells towards the surface away from their normal parabasal position. Once at the site of infection Langerhans' cells may be able to present HPV antigens locally to T lymphocytes or, having been activated by the local

Table 3 Percentage of Langerhans' cells (T6 positive dendritic cells) expressing MHC class II antigens

\begin{tabular}{|c|c|c|c|c|}
\hline & $\begin{array}{l}\text { DA6.231 } \\
\text { *Mean (range) \% }\end{array}$ & $\begin{array}{l}D R \\
\text { Mean (range) \% }\end{array}$ & $\begin{array}{l}D P \\
\text { Mean (range) } \%\end{array}$ & $\begin{array}{l}D Q \\
\text { Mean (range) } \%\end{array}$ \\
\hline $\begin{array}{l}\text { Normal } \\
(n=7) \\
\text { Koilocytosis only } \\
(n=4) \\
\text { CIN I } \\
(n=14) \\
\text { CIN II } \\
(n=8) \\
\text { CIN III } \\
(n=11)\end{array}$ & $\begin{array}{l}92 \\
(81-98) \\
73 \\
(63-95) \\
93 \\
(61-99) \\
88 \\
(65-100) \\
72 \\
(53-92)\end{array}$ & $\begin{array}{l}57 \\
(41-73) \\
94 \dagger \\
(64-117) \\
72 \dagger \\
(52-93) \\
81 \dagger \\
(61-94) \\
46 \\
(33-78)\end{array}$ & $\begin{array}{l}35 \\
(11-56) \\
11 \dagger \\
(4-26) \\
47 \\
(21-82) \\
46 \\
(27-69) \\
85 \dagger \\
(43-98)\end{array}$ & $\begin{array}{l}22 \\
(7-52) \\
20 \\
(9-46) \\
65 \ddagger \\
(10-91) \\
59 \dagger \\
(8-73) \\
57 \dagger \\
(4-81)\end{array}$ \\
\hline
\end{tabular}

*The percentage of Langerhans' cells staining positively with each anti-MHC class II monoclonal antibody was calculated for individua specimens before obtaining a mean value.

Significance of differences compared with normal group; $\dagger p<0.05 ; \ddagger p<0.01$ (Mann-Whitney U test) 
Table 4 No. of dendritic cells $/ \mathrm{mm}^{2}$ in samples from users and non-users of contraceptive pill

\begin{tabular}{lll}
\hline No. of cells $/ \mathrm{mm}^{2}$ & Users & Non-users \\
\hline Normal epithelium & 82 & 49 \\
(Mean (SEM)) & $(29)$ & $(14)$ \\
Koilocytosis only & 23 & 21 \\
(Mean (SEM)) & $(13)$ & $(5)$ \\
CIN I & 49 & 26 \\
(Mean (SEM)) & $(15)$ & $(9)$ \\
CIN II & 29 & 25 \\
(Mean (SEM)) & $(6)$ & $(10)$ \\
CIN III & 13 & 9 \\
(Mean (SEM)) & $(6)$ & $(4)$ \\
\hline
\end{tabular}

viral infection, may leave the site and present HPV antigens in draining lymph nodes.

\section{MHC CLASS II EXPRESSION BY LANGERHANS' CELLS}

Table 2 shows that not all T6 positive Langerhans' cells were stained with the pan-class II marker DA6.231. This has been reported previously ${ }^{623}$ using other monoclonal antibodies to class II antigens, and may reflect the variable expression of these antigens by Langerhans' cells. HLA-DR expression by Langerhans' cells was significantly increased in koilocytic lesions and in CIN grades I and II, and HLA-DQ expression was significantly increased in all grades of CIN with the increase being most pronounced in CIN I (table 3). Thus although Langerhans' cells are reduced in number compared with normal epithelium, those present seem to be more highly "activated".
The parallel increase in HLA-DR and HLA-DQ expression by Langerhans' cells in CIN is consistent with reports from other groups that HLA-DQ expression correlates in general with HLA-DR. ${ }^{24}$ HLA-DQ is almost always expressed at a much lower level than HLA-DR, ${ }^{24}$ so that detection of HLA-DR positive, HLA-DQ negative cells may reflect the limit in sensitivity of the technique used.

Most published work suggests that the expression of HLA-DQ and HLA-DP antigens have the same functional importance as the expression of HLA$D_{R}{ }^{25-27}$ Navarette et $a l,{ }^{28}{ }^{29}$ however, proposed that HLA-DQ has a function distinct from HLA-DR. They report that while HLA-DR is implicated in the induction of the proliferation of helper/inducer $T$ lymphocytes, HLA-DQ has a predominantly modulatory function entailing the generation of suppressor or cytotoxic $\mathrm{T}$ lymphocytes, or both. This may be of relevance to the present study, as an increase in the relative proportion of cytotoxic/suppressor $T$ cells has been reported previously in CIN. ${ }^{30}$ The increase may be related to the increased expression of HLADQ which we found to be particularly noticeable in CIN I, and which may permit a more rapid progression of the neoplastic process.

\section{COMBINED USE OF CONTRACEPTIVE PILL AND}

MHC CLASS II EXPRESSION

In this part of the study we found that Langerhans' cells were increased in number in the epithelium of the cervical transformation zone of users, compared with non users, and that this increase was significant in patients with CIN I (table 4). This has not been

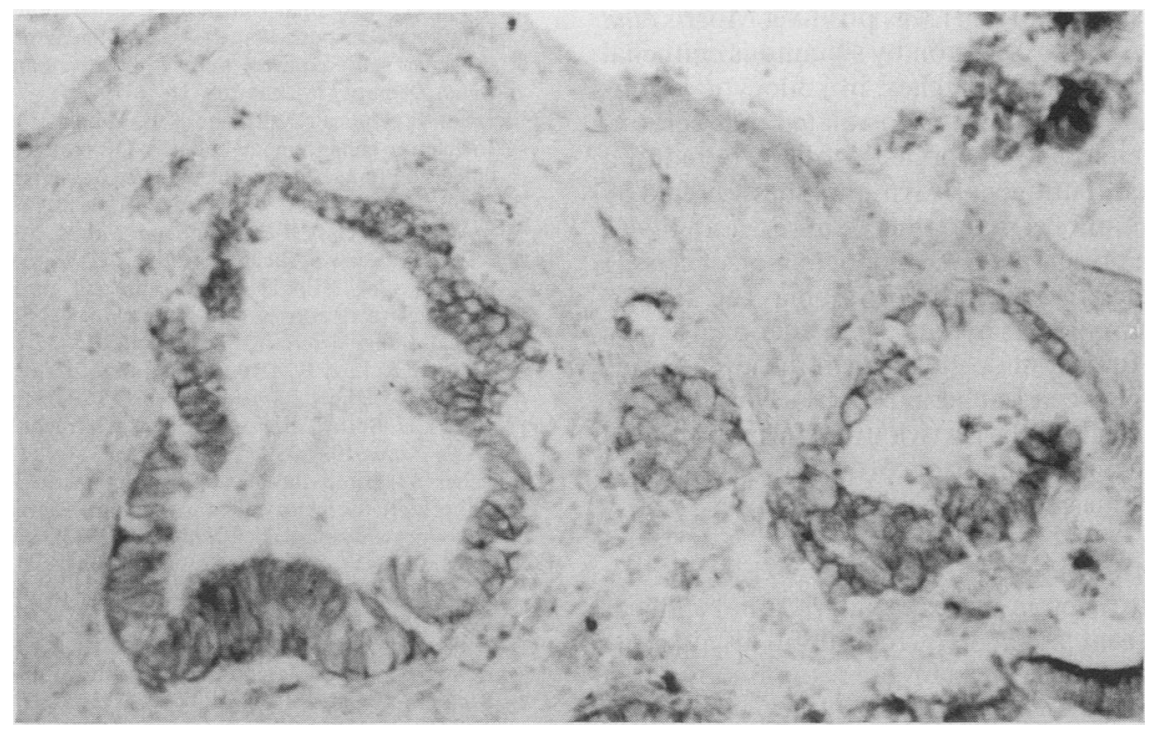

Fig 3 DA6.231 staining of normal columnar epithelium; adjacent squamous epithelium is negative. 
previously reported, although other workers have shown an impairment of non-specific peripheral blood lymphocyte proliferation in users ${ }^{31}$ and an increase in cervical mucus IgG and IgA. ${ }^{32}$ Perhaps the increased numbers of Langerhans' cells help start and amplify a local antibody response in the cervix. In any case it is interesting to note a difference between users and nonusers in view of the continuing controversy over the role of the pill in the aetiology of cervical cancer. ${ }^{33}{ }^{34}$

When smokers were compared with non-smokers, no difference in the number of Langerhans' cells or class II expression by Langerhans' cells could be detected (data not shown).

\section{EXPRESSION OF MHC CLASS II ANTIGENS BY COLUMNAR AND SQUAMOUS CERVICAL EPITHELIUM}

The expression of class II antigens by columnar epithelium lining endocervical glands was a chance finding as most sections studied contained no columnar epithelium. Expression of HLA-DR by endometrium has been reported to vary with the menstrual cycle ${ }^{35}$ being highest in the late proliferative phase and thus correlating with oestrogen receptor content. No apparent correlation between intensity of staining and stage of the menstrual cycle was found in the present study, but 11 of 19 subjects in this group were taking the pill and therefore not experiencing normal cycles. It would be useful to examine this in more detail.

In some cases $(14 \%)$ of CIN III the squamous epithelium exhibited positive staining with DA6.231, although no squamous epithelium from normal cervix or from areas of CIN I or II was positive. Morris et al reported HLA-DR expression by squamous epithelial cells in CIN III and, in patches, in koilocytic lesions with no associated CIN. ${ }^{5}$ It is postulated that keratinocytes $^{36}$ and endometrial epithelial cells ${ }^{35}$ are induced to express class II antigens by lymphokines secreted by infiltrating lymphocytes and thus acquire the ability to act as antigen presenting cells. Our detection of class II positive epithelial cells in CIN III may be further evidence to support this hypothesis. Functional assays should bring further understanding of the interactions taking place between Langerhans' cells, lymphocytes, and epithelial cells in the cervical transformation zone and of the clinical importance of class II antigen expression at this site.

We are grateful to Drs G E Smart and S Fletcher for enabling us to obtain biopsy material and clinical information from patients and for helpful discussions, and to the staff of the Lothian Area colposcopy clinic for their assistance. We thank Drs I Trowbridge, A Ziegler, and $\mathrm{K}$ Guy for the gifts of monoclonal antibodies, and Drs K Guy, J Ross, and Mrs E
McVittie for useful discussions. The Melville Trust provided a clinical research fellowship for RGH, and part of this work was funded by the Cancer Research Campaign. SEMH is a senior research fellow of the Medical Research Council.

\section{References}

1 Anonymous. Genital warts, human papillomaviruses and cervical cancer. [Editorial] Lancet 1985;ii:1045-6.

2 Cox MF, Meanwell CA, Maitland NJ, Blackledge G, Scully C, Jordan JA. Human papillomavirus type 16 homologous DNA in normal human ectocervix. Lancet 1986;ii:157-8.

3 Toon PG, Arrand JR, Wilson LP, Sharp DS. Human papillomavirus infection of the uterine cervix of women without cytological signs of neoplasia. Br Med J 1986;239:1261-4.

4 Thivolet J, Viac J, Staquet MG. Cell mediated immunity in wart virus infection. Int J Dermatol 1982;21:94-8.

5 Morris HHB, Gatter KC, Sykes G, Casemore V, Mason DY. Langerhans' cells in human cervical epithelium; effects of wart virus infection and cervical intraepithelial neoplasia. Br JObstet Gynaecol 1983;90:412-20.

6 Chardonnet Y, Viac J, Thivolet J. Langerhans' cells in human warts. Br J Dermatol 1986;115:669-75.

7 McArdle JP, Muller HK. Quantitative assessment of Langerhans' cells in human cervical intraepithelial neoplasia and wart virus infection. Am J Obstet Gynecol 1986;154:509-15.

8 Tay SK, Jenkins D, Maddox P, Campion M, Singer A. Subpopulations of Langerhans' cells in cervical neoplasia. $\mathrm{Br} J$ Obstet Gynaecol 1987;94:10-15.

9 Murphy GF, Bhan AK, Sato S, Harrist TJ, Mihm MC. Characterisation of Langerhans' cells by the use of monoclonal antibodies. Lab Invest 1981;45:465-8.

10 Dezutter-Dambuyant C, Cordier G, Schmitt D, Faure M, Laquoi C, Thivolet J. Quantitative evaluation of two distinct cell populations expressing HLA-DR antigens in normal human epidermis. Br J Dermatol 1984;111:1-11.

11 Pehamberger H, Stingl LA, Pogantsch S, Steiner S, Wolff K, Stingl G. Epidermal cell induced generation of cytotoxic $T$ lymphocyte responses against alloantigens or TNP modified syngeneic cells: requirement for Ia-positive Langerhans' cells. $J$ Invest Dermatol 1983;81:208-11.

12 Berman B, Duncan MR, Smith B, Ziboh VA, Palladino M. Interferon enhancement of HLA-DR antigen expression on epidermal Langerhans' cells. J Invest Dermatol 1985;84:54-8.

13 Watson AJ, Demars R, Trowbridge IS, Bach FH. Detection of a novel human class II HLA antigen. Nature 1983;304:358-61.

14 Pawelec GP, Shaw S, Ziegler A, Muller C, Wernet P. Differential inhibition of HLA-D or -SB directed secondary lymphoproliferative responses with monoclonal antibodies detecting human Ia-like determinants. J Immunol 1982;129:1070-5.

15 Lampson LA, Levy R. Two populations of Ia-like molecules on a human B cell line. J Immunol 1980;125:293-9.

16 Buckley CH, Butler EB, Fox H. Cervical intraepithelial neoplasia. $J$ Clin Pathol 1982;35:1-13.

17 Fletcher S. Histopathology of papillomavirus infection of the cervix uteri: the history, taxonomy, nomenclature and reporting of koilocyte dysplasias. J Clin Pathol 1983;36:616-24.

18 Carr MM, McVittie E, Guy K. Gawkrodger DJ, Hunter JAA. MHC class II antigen expression in normal human epidermis. Immunology 1986;59:223-7.

19 Thomas JA, Janossy G, Chilosi M, Pritchard J. Pincott JR. Combined immunologic and histochemical analysis of skin and lymph node lesions in histiocytosis X. J Clin Pathol 1982; 35:327-37.

20 Guy K, Van Heyningen V, Cohen BB, Deane DL, Steel CM Differential expression and serologically distinct subpopula- 
tions of human Ia antigens detected with monoclonal antibodies to alpha and beta chains. Eur J Immunol 1982;12:942-8.

21 De Jong MCJM, Blanken R, Nanninga J, van Voorstrader PC, Poppema S. Defined in situ enumeration of T6 and HLA-DR expressing epidermal Langerhans' cells: morphological and methodological aspects. J Invest Dermatol 1986;87:698-702.

22 McDougall JK, Beckman AM, Kiviat NB. Methods for diagnosing papillomavirus infection. Papillomaviruses. Ciba Foundation Symposia 1986;120:86-103.

23 Harrist TJ, Muhlbauer JE, Murphy GF, Mihm MC, Bhan AK. T6 is superior to Ia (HLA-DR) as a marker for Langerhans' cells and indeterminate cells in normal epidermis: a monoclonal antibody study. J Invest Dermatol 1985;80:100-3.

24 Sorrentino R, Corte G. The complexity of HLA-DQ molecules. In: Solheim BG, Moller E, Ferrone S, Eds. HLA class II antigens. A comprehensive review of structure and function. Berlin: SpringerVerlag, 1986:71-82.

25 Gonwa TA, Picker LJ, Raff HV, Goyert SM, Silver J, Stobo JD. Antigen presenting capabilities of human monocytes correlates with their expression of HLA-DS, an Ia determinant distinct from HLA-DR. J Immunol 1983;130:706-11.

26 Nunez G, Ball EJ, Myers LK, Stastny P. Allostimulating cells in man. Quantitative variation in the expression of HLA-DR and DQ molecules influences $T$ cell activation. Immunogenetics 1985;22:85-91.

27 Sanchez-Perez M, Shaw S. HLA-DP: current status. In: Solheim BG, Moller E, Ferrone S, eds. HLA class II antigens. A comprehensive review of structure and function. Berlin: SpringerVerlag, 1986: 83-108.

28 Navarrette C, Jaraquemada D, Fainboim L, et al. Genetic and functional relationship of the HLA-DR and HLA-DQ antigens.
Immunogenetics 1985;21:97-101.

29 Navarrette C, Jaraquemada D, Hui K, Awad J, Okoye R, Festenstein $H$. Differential functions and associations of HLA-DR and HLA-DQ (DC) antigens shown by serological, cellular and DNA assays. Tissue Antigens 1985;25:130-41.

30 Tay SK, Jenkins D, Maddox R, Singer A. Lymphocyte phenotypes in cervical intraepithelial neoplasia and human papillomavirus infection. Br J Obstet Gynaecol 1987;94:16-21.

31 Barnes EW, MacCuish AC, Loudon NB, Jordan J, Irvine WJ. PHA induced transformation and circulating auto antibodies in women taking the oral contraceptive pill. Lancet 1974;i: 878-900.

32 Chipperfield EJ, Evans BA. Effect of local infection and oral contraception on immunoglobulin levels in cervical mucus. Infect Immun 1975;11:215-21.

33 Piper JM. Oral contraceptives and cervical cancer. Gynecol Oncol 1985;22:1-14.

34 Francheschi S, La Vecchia C, Talamini R. Oral contraceptives and cervical neoplasia. Pooled information from retrospective and prospective epidemiologic studies. Tumori 1986;72:21-30.

35 Tabibzadeh SS, Bettica A, Gerber MA. Variable expression of Ia antigens in human endometrium and in chronic endometritis. Am J Clin Pathol 1986;86:153-60.

36 Lampert IA. Expression of HLA-DR (Ia-like) antigen on epidermal keratinocytes in human dermatoses. Clin Exp Immunol 1984;57:93-100.

Requests for reprints to: Dr R G Hughes, The Simpson Memorial Maternity Pavilion, Lauriston Place, Edinburgh EH3 9YW, Scotland. 